\title{
tolojisinde Proteomik
} Yaklaşımlar

\author{
Yasemin Uçal@ Aysel Ozpinar@
}

Acıbadem Mehmet Ali Aydınlar Üniversitesi, Tıbbi Biyokimya Anabilim Dalı, Istanbul, Türkiye

Yasemin Uçal, Dr. Öğr. Üyesi Aysel Özpınar, Prof. Dr.
Iletişim:

Dr. Öğr. Üyesi Yasemin Uçal

Acıbadem Mehmet Ali Aydınlar Üniversitesi,

Tibbi Biyokimya Anabilim Dalı, Istanbul, Türkiye

Tel: +902165004068

E-Posta: yasemin.furtun@acibadem.edu.tr

\section{ÖZET}

Tiroid bezinde görülen kanserler en sık görülen endokrin maligniteleri oluşturmaktadır ve bu kanserlerin insidansı son yıllarda önemli ölçüde artmıştır. Günümüzde çok sık rastlanan tiroid nodüllerinin histopatolojik tanısının konulmasını sağlayan en güvenilir ve ucuz yöntem İnce lğne Aspirasyon Biyopsisi'dir (iïAB). Ancak, ayırıcı tanıda ayrım kriterlerinin yeterli olmayışı bazı nodüllerin histopatolojik tanılarının başarıyla konulamamasına neden olmaktadır. Bu amaçla son 40 yıldan beri birçok moleküler teknik geliştirilmiş ve farklı moleküler hedeflerin tiroid kanserinin ayırıcı tanısında kullanııması amaçlanmıştır. Ayıııcı tanıya katkısı olabileceği düşünülen genetik mutasyonlar ya da hücre yüzey belirteçleri prevelans farklılıkları nedeniyle klinikte yaygın olarak kullanılmamaktadır.

Son yıllarda hızla gelişmekte olan proteomik tekniklerin; nodüllerde belirli zamanda belirli yerde bulunan proteinlerin yapısını, yerleşimini, miktarını, translasyon sonrası modifikasyonunu ve protein-protein etkileşimini aydınlatmasından dolayı, tiroid patolojisinde ayıııc tanıya katkı sağlayacağı düşünülmektedir. Bu derlemede, gelişen proteomik teknolojilerin klinik açıdan tiroid dokularına uygulanmasına odaklanılacak ve ayırıc tanıya katkı sağlayabilecek potansiyel biyobelirteçlerin olası klinik kullanımları vurgulanacaktır.

Anahtar sözcükler: Tiroid Patolojisi, proteomiks, kütle spektrometresi

\section{PROTEOMICS IN THYROID PATHOLOGY}

\section{ABSTRACT}

Thyroid cancer is the most common endocrine malignancy, of which the incidence has increased worldwide in the past years. The most reliable and inexpensive method for establishing the histopathological diagnosis of thyroid nodules is Fine Needle Aspiration Biopsy (FNAB). However, the lack of discrimination (distinctive) criteria in differential diagnosis leads to the failure of the successful diagnosis of some nodules. For this purpose, several molecular techniques have been developed and several molecules were targeted for the differential diagnosis of thyroid nodules. However, genetic mutations or cell surface markers that might contribute to the differential diagnosis are not widely used due to the differences in prevalence.

In the recent years, rapidly developing proteomic techniques are thought to contribute to the differential diagnosis in thyroid pathology as proteomics provide information about the structure, location, quantity, posttranslational modifications and protein-protein interactions of the proteins found in certain places in the nodules. In this review, we will focus on the clinical applications of proteomic techniques on thyroid tissues and emphasize the clinical usage of potential biomarkers that may contribute to the differential diagnosis.

Keywords: Thyroid pathology, proteomics, mass spectrometry

$\mathbf{T}$ iroid bezinde görülen kanserler en sık görülen endokrin maligniteleri oluşturmaktadır ve bu kanserlerin insidansı son yıllarda önemli ölçüde artmıştır. Insidansta görülen bu artışın nedeni gelişen tanı teknikleri ve sağlık hizmetlerinin insanlara daha rahat ulaşması ile ilişkili olduğu öne sürülmektedir $(1,2)$. Tiroid
Revizyon Tarihi : 05 Mart 2018

Kabul Tarihi : 22 Mart 2018 
bezinin foliküler hücrelerinden köken alan papiller tiroid kanseri (PTK) ve foliküler tiroid kanseri (FTK) iyi diferansiye tiroid kanserlerini oluştururken, aynı hücre tipinden köken alan anaplastik tiroid kanserleri (ATK) en agresif tiroid bezi kanserlerini oluşturmaktadır. Ayrıca, tiroid bezinin C hücrelerinden medüller tiroid kanseri (MTK) köken almaktadır. Bu hücreler tiroid hormonu sentezlememekte, bunun yerine kalsitonin hormonu üretmektedirler. Tiroid kanserlerinin etyolojik faktörleri henüz tam olarak bilinmemektedir. Ancak, II. Dünya Savaşı esnasında Hiroşima ve Nagazaki'de atom bombası ve daha sonra Çernobil kazası sonrasında tiroid kanserlerinin görülme sıklığı artmıştır $(3,4)$. Ülkemizde ise, Türkiye Halk Sağlığı Kurumu Kanser Daire Başkanlığı'nın Türkiye'de Kanser Kayıtçılığı verilerine bakıldığında, tiroid kanserlerinin görülme sıklığının dünyada görülme sıklığından yaklaşık 4 kat daha fazla olduğu belirtilmektedir (5).

Tiroid tümörlerinde cerrahi operasyon uygulanan ilk tedavi yöntemidir. Ancak, tiroid nodüllerinin benign ve malign olarak preoperatif ayrımının yapılması hastaların aşırı tedavi edilmesinin önüne geçilmesi veya gereksiz cerrahi operasyona bağlı morbiditenin önlenmesi açısından önem arz etmektedir. Tiroid nodüllerinin benign ve malign ayrımının yapılmasında kullanılan altın standart yöntem ince iğne aspirasyon biyopsisidir (iiAB). Her ne kadar Ii $A B$ yöntemi güvenilir ve uygun maliyetli bir yöntem olsa da, IïAB sonucu 'malignite için belirsiz/şüpheli' olan tiroid nodülleri vardır. Bu nodüllerin benign ve malign ayrımının tam olarak yapılabilmesi için ayrım tekniklerinin geliştirilmesi veya ayırıcı tanıya katkısı olabilecek biyobelirteçlerin belirlenmesi tiroid patolojisi için önem teşkil etmektedir. Tiroid malignitelerini doğru tespit etmek amacıyla yaklaşık 40 yıldan beri birçok moleküler teknik geliştirilmeye çalışılmış ve birçok molekül hedeflenmiştir (6). Bu amaçla yapılan ilk çalışmalarda hasta serum örnekleri analiz edilmiş ve bu örneklerden elde edilecek potansiyel biyobelirteçlerin duyarlıı̆ının ve özgüllüğünün yüksek olması hedeflenmiştir. En önemli serum biyobelirteçlerinden olan kalsitonin MTK'nın biyobelirtecidir, ancak kalsitonin analizinin de kullanılan yöntemlere göre farklılık gösterdiği bildirilmektedir (7). Tiroid patolojisinde birçok genetik mutasyon ve hücre yüzey belirteçleri de ayırıcı tanı için hedeflenmiştir. Örneğin, hedeflenen moleküllerden BRAF V600E, RET/PTC rearanjmanı, RAS, PAX8/ peroksizom proliferatör-aktive reseptörü (PPAR gamma) sporadik mutasyonları PTK'nın histopatolojik varyantları arasında farklılık göstermektedir (6). Bir diğer moleküler biyobelirteç olan RET/PTC rearanjmanının da yine PTK olgularında görülme sıkığının \%5 ile \%80 arasında değiştiği bildirilmektedir (8). Aynı zamanda, tiroid patolojisinde ayırıcı tanıya katkı sağlaması için çeşitli immünohistokimyasal biyobelirteçler de araştırılmıştır. Ancak yapılan çalışmalar neticesinde, benign lezyonları malign lezyonlardan ayırt etmek için yeterli duyarlıığa ve özgüllüğe sahip tek başına kullanılabilecek bir immünohistokimyasal biyobelirteç bulunamamıştır. Buna göre, çeşitli antikorların panel halinde kullanılmasıyla farklı tiroid kanseri tiplerinin tanısına katkı sağlayabileceği belirtilmiştir. Şuana kadar önerilen immünohistokimyasal belirteçler, hücre adezyonu (galektin-3), gen transkripsiyon kontrolü (tiroid transkripsiyon faktörü 1 [TTF-1]), hücre döngüsü regülasyonu (p27, siklin D1) ve hücre yapısından (sitokeratin [CK]-19) sorumlu çeşitli molekülleridir $(9,10)$. Ayrıca, mezotelyoma antikoru (HBME-1) PTK'da genellikle güçlü ve diffüz olarak ifade edildiği için özellikle panel içerisinde kullanılması durumunda PTK teşhisine olanak sağlayacağı belirtilmektedir (11). Ancak önerilen imünohistokimyasal belirteçlerin panel halinde kullanılmasına rağmen birbirinden çok farklı duyarlılık ve özgüllükte sonuçların elde edildiği literatürdeki çeşitli çalışmalarla gösterilmiştir (12-14).

Özellikle son yıllarda, gelişen proteomik teknikler yardımıyla tiroid nodüllerinin ayırıcı tanısına katkı sağlamak amacıyla yapılan çalışmaların sayısı hızla artmaktadır. Bu derlemede, gelişen proteomik teknolojilerin klinik bağlamda tiroid dokularına uygulanmasına odaklanılacak ve ayırıcı tanıya katkı sağlayabilecek potansiyel biyobelirteçlerin olası klinik kullanımları vurgulanacaktır.

\section{Proteomik teknikler}

Proteom, genom tarafından kodlanan bütün proteinleri tanımlamaktadır. Proteomik ise, belirli bir hücrenin, dokunun veya organizmanın genleri tarafından üretilen proteinlerin yapı, işlev ve etkileşimlerinin yani kısaca proteomunun anlaşılmasına yönelik yapılan çalışmalardır. Proteomik teknikler arasında, proteinlerin geniş kapsamlı analizine imkan sağlayan kütle spektrometresi yöntemleri ön plana çıkmaktadır. Bu çalışmalarda, proteinlerin tanımlanması ve miktarlarının tayini, protein etkileşimlerinin aydınlatılması ve protein modifikasyonlarının ve yerlerinin belirlenmesi üzerinde durulmaktadır.

1980 'li yıllar ve 1990 'lı yılların başında, protein kimyasındaki teknolojik gelişmeler esas olarak jellerle ayrılmış proteinlerin tanımlanmasına yönelikti. Bunun için sıklıkla başvurulan yöntem Edman tarafından geliştirilen, protein ve peptidlerin aşamalı olarak bozunmasına yönelik protein sekanslamasıydı. Kütle spektrometresine dayalı yöntemlerin peptid veya proteinlerin analizinde kullanımasında molekülün parçalanmadan iyonlaşmasına izin 
veren yöntemlerin geliştirilmesi gerekiyordu. Geliştirilen elektrosprey iyonizasyonu (ESI) ve matriks destekli lazer desorpsiyon/iyonizasyon (MALDI) yöntemleri ile peptidlerin ve proteinlerin iyonizasyonları yüksek duyarlılıkta aşırı fragmantasyon olmadan gerçekleşmeye başlamıştır. Kütle spektrometresindeki bu gelişmelerle birlikte, özellikle iki boyutlu jel elektroforezinde çözülebilen proteinlerin tanımlanması gerçekleştirilmiş ve bu sayede nispeten büyük ölçekli protein çalışmalarına olanak sağlanmıştır. İki boyutlu jel elektroforezinde, iki boyutta ayrım gerçekleşmektedir. Birinci boyutta proteinler izoelektrik noktalarına göre ayrılmakta, ardından ikinci boyutta ayrım ise poliakrilamid jel elektroforezi ile gerçekleşmektedir. Ancak, bu yöntemin getirdiği teknik kısıtlamalar nedeniyle aşırı asidik veya bazik proteinlerin, membran proteinlerinin ve aşırı büyük veya küçük proteinlerin iki boyutlu jel elektroforezinde gösterilmelerinde problem yaşanmıştır (15). 1995 yılında Hunt ve arkadaşları, karmaşık peptid karışımlarını likit kromatografisi-kütle spektrometresi (LC-MS) yöntemini kullanarak jelden bağımsız olarak analiz eden bir yaklaşım için zemin oluşturmuşlardır (16). Bu yaklaşım sayesinde LC-MS yönteminin karmaşık protein örneklerini analiz etmek için güçlü bir araç olabileceği öne sürülmüş ve jelden bağımsız teknolojilerin geliştirilmesine yönelik önemli bir adım oluşturulmuştur. LC-MS tabanlı proteomik tekniklerde, karmaşık protein karışımları öncelikle enzimatik parçalanmaya tabi tutulmaktadır. Ardından, ortaya çıkan peptid ürünleri bir kütle spektrometresi kullanılarak analiz edilmektedir.

Ayrıca, desorpsiyon ve iyonizasyon tekniklerinin ve uçuş zamanlı küte spektrometrelerinin önemli ölçüde iyileştirilmeleri neticesinde proteinlerin daha önce hiç olmadığı kadar yüksek hassasiyet ve kütle doğruluğu ile analiz edilmesine imkan sağlanmıştır. Bu teknolojinin ince doku kesitlerinin analizine uygulanması ile hastalıklı hücreler ve çevreleri arasındaki karmaşık etkileşimin moleküler düzeyde uzamsal ve anatomik ilişkilerle birlikte incelenmesine başlanmıştır. MALDI-Görüntüleme Kütle Spektrometresi adı verilen bu yöntem ile tek bir doku kesitinin analiziyle doku mimarisiyle ilişkili olan protein spesifik haritalar binlerce farklı protein türü için aynı anda elde edilebilmektedir (17).

\section{Tiroid patolojisinde uygulanan proteomik teknikler}

Tiroid patolojisinde uygulanan ilk proteomik teknik iki boyutlu jel elektroforezidir. Bu çalışmaların ilki, Brown ve arkadaşları tarafından 2006 yılında PTK dokuları ve foliküler adenom (FA) dokularının normal tiroid dokusu ile karşılaştırıldığı çalışmadır (18). Yapılan çalışmanın sonucuna göre,
PTK ve FA arasında 31 proteinin istatistiksel olarak anlamlı değiştiği belirtilmektedir. Özellikle, S100A6 proteininin PTK ve FA arasında 6.5 kat farklılık gösterdiği bildirilmiş ve bu proteinin doğruluğu immünohistokimya yöntemi ile araştırılmıştır. Literatürde, $\mathrm{Ca} 2+$ bağlayan $\mathrm{S} 100$ protein ailesinin A grubuna ait $\mathrm{S} 100 \mathrm{~A} 6$ proteininin proliferasyon, apoptoz ve hücre iskeleti ile ilgili çeşitli görevleri olduğu bildirilmektedir (19). Brown ve arkadaşları tarafından immünohistokimya ile doğrulaması yapılan çalışmanın sonuçlarına göre benign ve malign tiroid neo-plazmlarını $\% 85$ doğuluk ve \%69 özgüllükle ayırabildiği gösterilmiştir (18). İki boyutlu jel elektroforezinin kullanıldığı bir diğer çalışmada ise, FTK ve FA örnekleri karşılaştırılmıştır. Buna göre, protein disülfid izomeraz, kalretikulin, katepsin $B$ ve aneksin $A 3$ gibi proteinlerin FTK'da diferansiyel olarak düzenlendiği gösterilmiştir (20). Ancak, FTK'da diferansiyel olarak değiştiği gösterilen proteinlerin, FTK'da aktif olan PI3K/Akt sinyal yolağı ya da FTK'da mutasyonu tespit edilen RAS veya PAX8/PPAR ile ilişkisinin olmadığı söylenmiştir. Krause ve arkadaşları tarafından yine 2 boyutlu jel elektroforezi yöntemi kullanılarak soğuk tiroid nodüllerinin protein profilleri araştırıımıştır. Bu çalışmanın sonucunda ise, soğuk nodüllerde sağlıklı tiroid dokusuna kıyasla tiroid hücre proliferasyonu, reaktif oksijen türleri ve detoksifikasyon mekanizmasına ilişkin proteinlerin arttığı gösterilmiştir (21). PTK hastalarının, BRAF V600E mutasyonu taşıyan bir alt sınıfı, Puxeddu ve arkadaşları tarafından yapılan çalışmada kontrollerle karşılaştııılmıştır. Yapılan iki boyutlu jel elektroforezi ve kütle spektrometresi sonuçlarına göre, BRAF V600E mutasyonu taşıyan tümör dokularında 19 farklı proteinin belirgin biçimde arttığı ve 5 farklı proteinin azaldığı belirlenmiştir. İki grup arasında diferansiyel farklılık gösteren proteinlerin, mitokondriyel proteinler, reaktif oksijen türleri ve apoptoz ile ilişkili proteinler olduğu tespit edilmiştir. Özellikle tümörde azalma gösteren proteinlerin daha önceki çalışmaların sonuçlarıyla kısmen uyumsuz olması, Puxeddu ve arkadaşları tarafından kullanılan proteomik tekniğin farklı olması ve BRAF V600E mutasyonu taşıyan ve taşımayan PTK'lar arasındaki olası biyolojik heterojenitenin bir sonucu olarak açıklanmıştır (22). Sofiadis ve arkadaşları ise 2 boyutlu jel elektroforezi ile yapılan çalışmaları bir basamak yukarı taşımış ve FTK, FA, PTK ve normal tiroid dokuIarını analiz etmişlerdir. Tanımladıkları proteinler arasından 14-3-3 protein beta/alfa ve zeta/delta, peroksiredoksin 6, selenyum bağlayıcı protein 1 , protein disülfid izomeraz öncülü, aneksin A5, tübülin alfa-1B zinciri gibi proteinler seçilip, western blot ile doğrulamaları yapılmıştır. Bu çalışmada tanımlanan proteinlerin, önceki bulguları doğruladığı belirtilmektedir (23). Yapılan bir diğer çalışmada ise, lenf nodu metastazı olan ve olmayan PTK vakalarında farklı şekilde ifade edilen proteinler iki boyutlu jel elektroforezi 
ile araştırılmışıtr. Çalışmanın sonuçlarına göre, lenf nodu metastazı olan grupta ara filamanlardan vimentin proteininin arttığı, lenf nodu metastazı olmayan grupta ise Isı şok proteini 60 (HSP60), süper-oksit dismutaz 2 (SOD2) ve fosfatidil etanolamin-bağlayıcı protein 1 (PEBP1) proteininin arttığı belirlenmiş̧ir. Genel olarak bakıldığında bu çalışmaların sonucu olarak hücre proliferasyonunda görevli proteinlerin, mitokondriyel ve endoplazmik retikulumla ilişkili proteinlerin, hücre iskelet proteinlerinin ve çeşitli sinyal yolaklarından sorumlu proteinlerin tiroid kanserlerinde farklılık gösterdiği ortaya konmuştur. Bu çalışmaların sonuçları önemli olmakla birlikte, iki boyutlu jel elektroforezinin yöntem kaynaklı kısıtlamaları nedeniyle, çalışmaların örnek sayısının az olduğu ve ortaya çıkarılan proteinlerin yalnızca iki boyutlu jel elektroforezinde jele geçebilen ve dolayısıyla tanımlaması yapılabilen proteinler olduğu göz önünde bulundurulmalıdır.

Gelişmiş kütle spektrometresi kullanılan yeni proteomik yaklaşımlar sayesinde binlerce proteinin ifadesini açığa çıkaran daha derin kantitatif analizler mümkün kılınmaktadır. Bu bağlamda, Martinez-Aguilar ve arkadaşları normal tiroid dokusunu ve tiroid bezinde görülen en yaygın 3 tümörün (FA, FTK ve PTK) protein profillerini geniş örneklem büyüklüğünde veri-bağımsız yaklaşım ile kütle spektrometresinde analiz etmişlerdir. Yapılan bu çalışma, literatürde şu ana kadar tiroid dokusunda yapılan en kapsamlı proteomik çalışmayı oluşturmaktadır (24). Buna göre, 32 örnekte 1600 'ün üzerinde protein tanımlaması yapılmıştır. Foliküler tümörlerde, tümör supresör ve aynı zamanda terapötik hedef olan decorin protein miktarının önemli ölçüde azaldığı gösterilmiştir. Decorin, lözinden zengin proteoglikan ailesine ait bir hücre dışı matriks proteinidir (25). Bu proteinin çeşitli tümörlerde miktarının azaldığı literatürde belirtilmektedir; ancak tiroid kanserinde ilk kez bu çalışma ile protein miktarındaki azalma gösterilmiştir. Otofajiyi tetikleyen ve aynı zamanda tümör anjiyogenezini engelleyen decorin proteininin foliküler tümörlerde miktarının önemli ölçüde azaldığının gösterilmesi tiroid patolojisinde yapılacak ileriki çalışmalar için önem arz etmektedir. Martinez-Aguilar ve arkadaşlarının bir diğer önemli bulgusu ise PTK örneklerinde görülen proteomik değişikliklerin özellikle hücre temaslarının bozulması ve aktin iskeletindeki düzenlemelerden kaynaklandığı belirtilmektedir. Tiroid patolojisinde yapılan bir diğer çalışmada ise, Uçal ve arkadaşları tarafından kütle spektrometresi tabanlı etiketsiz miktar tespit yaklaşımı (label-free quantification) uygulanmış ve bu çalışmada PTK'nın klinikte en sık görülen alt varyantlarının (klasik varyant-PTK ve foliküler varyant-PTK) proteomik profilleri benign tiroid dokusu ile karşılaştırılmıştır (26). Yapılan çalışmada, toplam
18 örnekte 2500 'den fazla protein tanımlaması yapılmıştır. Elde edilen protein profillerine göre, foliküler varyant-PTK ve benign örnekler arasında net bir protein profil ayrımı olmadığı ortaya konmuştur. Çalışmanın bu sonucu özellikle Nikiforov ve arkadaşları tarafından 2016 yılında yayınlanan ve noninvazif enkapsüle foliküler varyant PTK'nın düşük risk nedeniyle "kanser dışı" olarak yeniden sınıflandırıldığı temel yayın ile tutarlıdır (27). Uçal ve arkadaşlarının proteomik yolak analizlerinin sonucuna göre, klasik varyant PTK'da aktin iskelet proteinlerinin belirgin bir şekilde değiştiği gösterilmiştir. Aynı çalışmanın bir diğer önemli bulgusu ise, hücre adezyonu ve hücre iskeleti organizasyonunun düzenlenmesinde görev alan IQGAP proteinlerinden, onkojenik özellikler gösteren IQGAP1'in klasik varyant-PTK'da, tümör baskılayıcı özellik gösteren IQGAP2'nin ise foliküler varyant-PTK'da miktarının artmasıdır. Bu bulgular göz önüne alındığında IQGAP proteinlerinin PTK'nın alt varyantlarında farklı düzenlemelerinin olduğunu düşündürtmektedir. Ayrıca, sunulan tüm sonuçlar gelişen teknoloji ve proteomik yöntemlerdeki iyileştirmeler sayesinde tiroid patolojisiyle ilgili her geçen gün yeni bir bilginin literatüre kazandırıldığını göstermektedir.

Tiroid proteomiksinde yenilikçi bir araç ise doku üzerinde doğrudan analize imkan tanıyan ve analitlerin lokalizasyonları ile ilgili bilgi sağlayan MALDI-Görüntüleme kütle spektrometresi yöntemidir (17). Bu yöntemin tiroid kanserine uygulanabilirliği ilk olarak Meding ve arkadaşları tarafından tiroid kanserinin de dahil olduğu 6 farklı tümörün spesifik protein profillerinin elde edilmesinin amaçlandığı pilot çalışmada gösterilmiştir (28). Daha sonra, kanser agresifliğine spesifik biyobelirteçleri belirlemek için lenf nodu metastazı olan ve olmayan PTK örnekleri üzerinde MALDIGörüntüleme kütle spektrometresi analizi yapılmıştır. Çalışmanın sonuçlarına göre, metastatik dokuda S100A6, S100A10 ve tiredoksin proteinlerinin miktar olarak arttığı gösterilmiştir (29). Bir başka PTK biyobelirteç çalışmasında nispeten küçük bir örnek seti kullanarak protein profillerine odaklanılmış ve PTK için ribozomal P2 proteini yeni bir biyobelirteç adayı olarak bildirilmiştir (30). Galli ve arkadaşları tarafından yapılan çalışmada ise doku mikrodizileri kullanılmış, malign ve benign örnekler için spesifik proteinler belirlenmiştir. Buna göre fibronektin (FINC), aktin-beta (ACTB), lamin A/C (LMNA) ve Isı şok protein 7C (HSP7C) proteinlerinin malign lezyonlarda arttığı gösterilmiştir (31). MALDI-Görüntüleme kütle spektrometresi yöntemi yalnızca biyobelirteç arayışı için değil, aynı zamanda peptid ve/ veya protein profil farklııkları göz önüne alınarak tiroid tümörlerinin çeşitli biyoinformatik yaklaşımlarla birlikte benign/malign ayrımının yapılmasında veya tümör alt tiplerinin belirlenmesinde kullanılmaktadır. Örneğin, Pagni ve 
arkadaşları PTK ile ilişkili proteinleri tanımlamak için sitolojik tiroid numunelerini MALDI-Görüntüleme kütle spektrometresi ile incelemiş ve bu yöntemi kullanarak sitolojik numunelerin benign veya malign ayrımını yapmışlardır (32). Pietrowska ve arkadaşları tarafından yapılan bir diğer çalışmada ise formalinle fikse edilip parafine gömülmüş tiroid dokuları kullanılmış ve tümör odaklarının yarı denetimli olarak keşfedilmesi yöntemi uygulanmıştır. Buna göre, elde edilen peptid profilleri kullanılarak tiroid epitelinden köken alan malignitelerin MTK'dan ayrımının yapıldığı bildirilmiştir (33). MALDI-Görüntüleme kütle spektrometresi yönteminin, tiroid malignitelerinin sınıflandırılması veya malign/benign ayrımının yapılmasında umut vadeden bir strateji olduğu göze çarpmaktadır.

\section{Tiroid dokusundaki proteomik çalışmalara özgü teknik zorluklar}

Tiroid dokusunda proteomik alanında yapılan sınırlı sayıda çalışma mevcuttur. Bunun en temel nedenini tiroid dokusunun doğasından kaynaklanan teknik zorluklar oluşturmaktadır. Tiroid hormon sentezinde önemi olan tiroglobulinin tiroid dokusunda yaygın olarak olarak bulunması ve kişiden kişiye geniş bir varyasyonda miktarının değişiklik göstermesi bu problemlerin en başında gelmektedir. Örneğin, tiroglobulin miktarı yaklaşık 75 mg/ ml'yi bulabilirken, çok daha az bulunan proteinler (interlökinler, $<1$ ng/ml) tiroglobulin nedeniyle baskılanmaktadır. Hastalıkların doğası düşünüldüğünde özellikle az bulunan

\section{Kaynaklar}

1. Lim H, Devesa SS, Sosa JA, Check D, Kitahara CM. Trends in Thyroid Cancer Incidence and Mortality in the United States, 1974-2013. JAMA. United States; 2017;317:1338-48. [CrossRef]

2. Zevallos JP, Hartman CM, Kramer JR, Sturgis EM, Chiao EY. Increased thyroid cancer incidence corresponds to increased use of thyroid ultrasound and fine-needle aspiration: a study of the Veterans Affairs health care system. Cancer. United States; 2015;121:741-6. [CrossRef]

3. Furukawa K, Preston D, Funamoto S, Yonehara S, Ito M, Tokuoka S, et al. Long-term trend of thyroid cancer risk among Japanese atomicbomb survivors: 60 years after exposure. Int J cancer. 2013;132:12226. [CrossRef]

4. Nikiforov YE. Radiation-induced thyroid cancer: what we have learned from chernobyl. Endocr Pathol. 2006;17:307-17.

5. T.C. Sağlık Bakanlığı HSGMKDB. Türkiye'de Kanser Kayıtçılığı [Internet]. Available from: http://kanser.gov.tr/daire-faaliyetleri/ kanser-kayitciligi/108-türkiyede-kanser-kayitcigi.html

6. Grogan $\mathrm{RH}$, Mitmaker EJ, Clark $\mathrm{OH}$. The evolution of biomarkers in thyroid cancer-from mass screening to a personalized biosignature. Cancers (Basel). 2010;2:885-912. [CrossRef]

7. Bieglmayer C, Vierhapper H, Dudczak R, Niederle B. Measurement of calcitonin by immunoassay analyzers. Clin Chem Lab Med. 2007;45:662-6. [CrossRef] proteinlerin tespit edilmesi ve ayırıcı tanı, tedavi veya prognoz için kullanılabilirliklerinin araştırılması önem arz etmektedir (34). Ayrıca, tiroid bezinde az sitoplazmalı küçük hücreler bulunması ve tümör hücrelerinin doğal heterojenitesi (stroma, kan damarları ve eritrositler) proteomik analizlerin uygulanmasında problem çıkarmaktadır.

\section{Tiroid patolojisinde proteomik tekniklerin geleceği}

Gelişen teknolojiyle birlikte, proteomik tabanlı tekniklerin klinik ve biyolojik araştırmalar üzerindeki etkisi her geçen gün artmaktadır. Tıbbi araştırmalarda teşhis ve prognostik testlerin geliştirilmesi, potansiyel tedavi hedeflerinin belirlenmesi ve kişiselleştirilmiş hasta tedavisine yönelik çeşitli uygulamalarda proteomik tekniklerden yararlanıması söz konusudur. Tiroid patolojisinde tanıya yönelik gri alanlar hala mevcuttur ve özellikle bazı tiroid kanseri tiplerinin ayırıcı tanısına katkı sağlayacak biyobelirteçlerin araştırılması/bulunması önem arz etmektedir. Bu araştırmalar, kütle doğruluğu, çözünürlük, hassasiyet, özgüllük ve teknik gelişmeler açısından kütle spektrometresinin hızla devam eden ilerlemesinden faydalanacaktır. Ayrıca, sadece proteomiğin değil diğer "omik" yaklaşımlarının da tiroid patolojisine uygulanması gerekmektedir. Genomik, transkriptomik, lipidomik, metabolomik gibi diğer omik platformlarının da entegre olduğu bir sistem biyolojisi temelli yaklaşımda tiroid patolojisindeki eksik ve henüz bilinmeyen alanlar aydınlatılabilecektir.
8. Lloyd R V, Buehler D, Khanafshar E. Papillary Thyroid Carcinoma Variants. Head Neck Pathol. 20118;5:51-6. [CrossRef]

9. Fischer S, Asa SL. Application of immunohistochemistry to thyroid neoplasms. Arch Pathol Lab Med. 2008;132:359-72. [CrossRef]

10. Prasad ML, Pellegata NS, Huang Y, Nagaraja HN, de la Chapelle A, Kloos RT. Galectin-3, fibronectin-1, CITED-1, HBME1 and cytokeratin-19 immunohistochemistry is useful for the differential diagnosis of thyroid tumors. Mod Pathol; 2005;18:48-57. [CrossRef]

11. Liu $H$, Lin F. Application of immunohistochemistry in thyroid pathology. Arch Pathol Lab Med. 2015;139:67-82. [CrossRef]

12. Nasr MR, Mukhopadhyay S, Zhang $S$, Katzenstein AL. Immunohistochemical markers in diagnosis of papillary thyroid carcinoma: utility of HBME1 combined with CK19 immunostaining. Mod Pathol. 2006;19:1631-7. [CrossRef]

13. Cheung CC, EzzatS, Freeman JL, Rosen IB, Asa SL.Immunohistochemical Diagnosis of Papillary Thyroid Carcinoma. Mod Pathol. 2001;14:33842. [CrossRef]

14. Barroeta JE, Baloch ZW, Lal P, Pasha TL, Zhang PJ, LiVolsi VA. Diagnostic value of differential expression of CK19, Galectin-3, HBME-1, ERK, RET, and p16 in benign and malignant follicular-derived lesions of the thyroid: an immunohistochemical tissue microarray analysis. Endocr Pathol. 2006;17:225-34.

15. Magdeldin S, Enany $S$, Yoshida $Y, X u B$, Zhang $Y$, Zureena $Z$, et al. Basics and recent advances of two dimensional- polyacrylamide gel electrophoresis. Clin Proteomics. 2014;11:16. [CrossRef] 
16. Appella E, Padlan EA, Hunt DF. Analysis of the structure of naturally processed peptides bound by class I and class II major histocompatibility complex molecules.. EXS. 1995;73:105-19.

17. Ucal Y, Durer ZA, Atak H, Kadioglu E, Sahin B, Coskun A, et al. Clinical applications of MALDI imaging technologies in cancer and neurodegenerative diseases. Biochim Biophys Acta. 2017;1865:795816. [CrossRef]

18. Brown LM, Helmke SM, Hunsucker SW, Netea-Maier RT, Chiang SA, Heinz $D E$, et al. Quantitative and qualitative differences in protein expression between papillary thyroid carcinoma and normal thyroid tissue. Mol Carcinog. 2006;45:613-26. [CrossRef]

19. Donato R, Sorci G, Giambanco I. S100A6 protein: functional roles. Cell Mol Life Sci. 2017;74:2749-60. [CrossRef]

20. Netea-Maier RT, Hunsucker SW, Hoevenaars BM, Helmke SM, Slootweg PJ, Hermus AR, et al. Discovery and validation of protein abundance differences between follicular thyroid neoplasms. Cancer Res. 2008;68:1572-80. [CrossRef]

21. Krause K, Karger S, Schierhorn A, Poncin S, Many M-C, Fuhrer D. Proteomic profiling of cold thyroid nodules. Endocrinology. 2007;148:1754-63. [CrossRef]

22. Puxeddu E, Susta F, Orvietani PL, Chiasserini D, Barbi F, Moretti S, et al. Identification of differentially expressed proteins in papillary thyroid carcinomas with V600E mutation of BRAF. Proteomics - Clin Appl. 2007;1:672-80. [CrossRef]

23. Sofiadis A, Becker S, Hellman U, Hultin-Rosenberg L, Dinets A, Hulchiy $M$, et al. Proteomic profiling of follicular and papillary thyroid tumors. Eur J Endocrinol. 2012;166:657-67. [CrossRef]

24. Martinez-Aguilar J, Clifton-Bligh R, Molloy MP. Proteomics of thyroid tumours provides new insights into their molecular composition and changes associated with malignancy. Sci Rep. 2016;6:23660. [CrossRef]

25. Järvinen TH, Prince S. Decorin: A Growth Factor Antagonist for Tumor Growth Inhibition. Biomed Res Int. 2015;2015:654765. [CrossRef]
26. Ucal Y, Eravci M, Tokat F, Duren $M$, Ince U, Ozpinar A. Proteomic analysis reveals differential protein expression in variants of papillary thyroid carcinoma. EuPA Open Proteomics. 2017;17:1-6. [CrossRef]

27. Nikiforov YE, Seethala RR, Tallini G, Baloch ZW, Basolo F4, Thompson LD al et. Nomenclature revision for encapsulated follicular variant of papillary thyroid carcinoma: A paradigm shift to reduce overtreatment of indolent tumors. JAMA Oncol. 2016;2:1023-9. [CrossRef]

28. Meding S, Nitsche U, Balluff B, Elsner M, Rauser S, Schone C, et al. Tumor classification of six common cancer types based on proteomic profiling by MALDI imaging. J Proteome Res. 2012;11:1996-2003. [CrossRef]

29. Nipp $M$, Elsner $M$, Balluff $B$, Meding $S$, Sarioglu $H$, Ueffing $M$, et al. S100-A10, thioredoxin, and S100-A6 as biomarkers of papillary thyroid carcinoma with lymph node metastasis identified by MALDI Imaging. J Mol Med. 2012;90:163-74. [CrossRef]

30. Min K, Bang J, Kim KP, Kim W, Lee SH, Shanta SR, et al. Imaging masS spectrometry in papillary thyroid carcinoma for the identification and validation of biomarker proteins. J Korean Med Sci. 2014;29:93440. [CrossRef]

31. Galli M, Pagni F, De Sio G, Smith A, Chinello C, Stella M, et al. Proteomic profiles of thyroid tumors by mass spectrometry-imaging on tissue microarrays. Biochim Biophys Acta. 2017;1865:817-27. [CrossRef]

32. Pagni F, De Sio G, Garancini M, Scardilli M, Chinello C, Smith AJ, et al. Proteomics in thyroid cytopathology: Relevance of MALDI-imaging in distinguishing malignant from benign lesions. Proteomics. 2016;16:1775-84. [CrossRef]

33. Pietrowska M, Diehl HC, Mrukwa G, Kalinowska-Herok M, Gawin M, Chekan M, et al. Molecular profiles of thyroid cancer subtypes: Classification based on features of tissue revealed by mass spectrometry imaging. Biochim Biophys Acta. Netherlands; 2017;1865:837-45.

34. Krause K, Jeßnitzer B, Fuhrer D. Proteomics in thyroid tumor research. J Clin Endocrinol Metab. 2009;94:2717-24. [CrossRef] 